\title{
NOTICES OF PUBLICATIONS
}

by WERNER GREUTER

\section{OPTIMA}

1. Frédéric MÉDAIL \& Gianniantonio DOMINA (ed.) - XV OPTIMA Meeting, June 6-11, 2016. Montpellier. Abstracts. Oral presentations. Poster presentations. - Orto Botanico ed Herbarium Mediterraneum, Palermo, 2016 (ISBN 978-88-903108-7-4). 183 pages; paper. [Received June 2016].

Organised under the partnership of Tela Botanica, the Conservatoire Botanique National Méditerranéen de Porquerolles, and the University of Montpellier, the XV OPTIMA Meeting in Montpellier was attended by ca. 230 botanists from 25 countries. There were 17 half-day symposia, not counting a memorial symposium for Pierre Quézel, recently deceased, half a day being devoted to a poster session. The present volume, with its 160 one-page abstracts received by the deadline ( 86 for symposium lectures, 74 for posters), aptly summarises the Meeting's scientific contents. The presence of a representative sample of bryological, lichenological and phycological topics deserves special mention.

W.G.

2. Gianniantonio DoMINA, Ridha EL MoKNI, Werner GReUTER \& Francesco Maria RAIMONDo (ed.) - Results of the 12th "Iter Mediterraneum" in Tunisia, 24 March - 4 April,
2014. [Occasional Papers from the Herbarium Greuter, 3; Bocconea, 27(1), ISSN 1120-4060 (print), 2280-3882 (online).] - Herbarium Mediterraneum Panormitanum, Palermo, 2015. 61 pages, black-and-white illustrations (photographs, maps), tables; paper. [Received January 2016].

Among the twelve Itinera Mediterranea that took place so far, the recent one to $\mathrm{Tu}$ nisia was certainly not the most rewarding botanically speaking. Spring was late to come that year, the flora was far behind what one might have expected, and the cool, stormy weather that prevailed throughout was not inspiring either; so that the total harvest of 1374 numbers collected, while below average, is still surprisingly high. No species new to science were found, yet three new country records and several first gatherings for a given province were made. On the credit side, let me note the presence in the group of bryophyte experts and a full-scale lichenologist, both of which made extensive collections not included in the above figure, being still only partly studied. Preliminary lists are presented here, with 55 bryophytes and 46 lichens half of the latter being new country records. What will definitely remain in the memory of all participants is the positive role played by local botanists: the unfailingly friendly, generous and competent assistance by the Tunisian hosts and the participation, in shifts, of no less than 14

Please send all items for announcement or review directly to the column editor: Prof. W. Greuter, Herbarium Mediterraneum, Orto Botanico, Via Lincoln 2/A, I-90133 Palermo. 
young, promising botanists, all keen to learn and enthusiastic plant freaks. They will no doubt be instrumental in raising new generations of experts to further the knowledge of the flora and vegetation of their country. W.G.

\section{Cryptogams}

\section{Mathias VUST - Inventaire des lichens} du canton de Genève. [Boissiera, 69, ISSN 0373-2975.] - Conservatoire et Jardin botaniques, Ville de Genève, 2015 (ISBN 978-2-8277-0085-1). 144 pages, 77 figures, mostly in colour (photographs, maps, graphs, facsimiles), 12 tables; laminated cover. [85 CHF (Europe); received January 2016]

Last year, when presenting Vust \& al.'s "Liste rouge des lichens du canton de Genève" (in OPTIMA Newslett. 42: (2-3). 2015), I noted: "the book includes a complete inventory of the Canton of Geneva's lichens". What then, one may ask in wonder, is the scope of the present book, which judging from is title is exactly that inventory? Is it a partial rehashing of the previous item? Or was my assessment inaccurate? Neither, I dare say, because the contents are not what one expects to find under that title. There is no comprehensive species list (which would have been redundant), but instead a number of items to complement the earlier volume: statistics and new graphs, historical data (both on local lichenological history and on landscape change through time), and an inventory (there we go!) of lichen communities, with excellent colour illustrations of characteristic habitats. A special boon for the interested specialist is the enumeration of Jean Mueller's lichen finds in the Canton, based not only on the published record but on the annotations in his personal, interleaved copy of his 1862 Catalogue and on his specimens in the Geneva herbarium (of which he was the keeper for 30 years). W.G.

\section{Phanerogams}

4. Enio NARDI - Il genere Aquilegia L. (Ranunculaceae) in Italia. The genus Aquilegia (Ranunculaceae) in Italy. Aquilegiarum italicarum in europaearum conspectus descriptio. - Polistampa, Firenze, 2015 (ISBN 978-88-5961518-7). 687 pages, 43 black-and-white figures and maps, 20 tables; paper. [45 €; received January 2016].

The author presents us with a comprehensive monographic revision of the columbines of Africa and Europe. The title of the book is therefore an understatement, as the word Europe appears only in the Latin subtitle and Africa not at all (the latter omission is explained by the fact that the genus extends to Africa only marginally, with two species endemic to Morocco and Algeria). All 54 species recognised by the author are treated in full, each with synonymy, description, specimen enumeration, notes, and indication of habitat, distribution, phenology, etc. Those 18 that occur in, and 11 of which are endemic to, Italy are treated in greater detail, with keys (one to identify herbarium material, another for live plants), illustrations, and maps of their Italian distribution. Yet the presentation of the 36 extra-Italian species is far more than a "synopsis", as the corresponding title, too modestly, tells.

The species treated here are only a fraction of the known columbines (80 to 400 species worldwide, depending on different authors' concepts), and Europe is not the primary centre of diversity of or origin for the genus. Southern Europe does, however, show secondary centres of diversity and speciation, to name the Balkan, Apennine and Pyrenean peninsulas and the Tyrrhenian islands. Europe is also the arguably main source of names published in the past under Aquilegia and the unchallenged centre of disparity of taxonomic concepts applied to the plants. Nardi's monograph has success- 
fully faced the challenge of defining and applying criteria for species-level classification that are based on a whole-population concept, noting but discounting individual aberrations, ontogenetic and environmentinduced variation, and the effects of introgressive hybridisation. He thus applies modern concepts supported by a lifetime's study of the plants in the wild and extrapolating the experience thus assembled to other, nonItalian populations.

The columbines are easy to treat in certain respects, e.g. by not presenting problems of generic delimitation; but they also present traits that make their classification hazardous, such as the general crossability, often indeed full interfertility of its component species; the lack of distinctive karyological differences (all appear to have a uniform karyotype with $2 n=14$ small chromosomes, no polyploidy or aneuploidy having so far been reported); and the loss, in pressed and dried material, of taxonomically relevant features such as colour and spatial configuration of the perianth. In order to better understand and interpret the observed diversity, Nardi has delved into aspects of the spatio-temporal development of the genus, from its presumed E Asian origin to its currently displayed chorological and variational patterns, taking into account pollination biology in particular. All this, and much more, is embedded in the general introductory part of the book, which provides fluidly and elegantly written information on many subjects of general interest to biologists, far beyond Aquilegia taxonomy.

The book is bilingual (English and Italian) throughout, except for some elements, such as synonymies, specimen enumerations, and Appendices, that are in Latin, or treated as such, to avoid unnecessary duplication. The Italian species are illustrated by drawings of unstated authorship but mostly initialled AM (Anne Maury). No nomenclatural novelties are included (required new names have all been validated in precursory papers), but numerous type designations are effected in a 50-page appendix discussing the typification of all relevant names and synonyms. An impressively thorough bibliography (55 pages) is found at the end.

Nardi's monograph is the result of a botanist's lifetime of study and endeavour, skilfully presented, devoted to a fascinating genus. The original dual designation of the plant as Columbina and Aquilina, still used by Mattioli, depicts and interprets its initially nodding flower as a ring of five doves in the act of alighting, which, inverted through anthesis, become the talons of an eagle's foot. The Medieval corruption of Aquilina to Aquilegia, with its usual but less plausible etymology of "[rain]water-collecting", adds an endearing humorous touch to the object of this scholarly masterpiece. W.G.

\section{Salvatore BRULlo \& Matthias ERBEN - The genus Limonium (Plumbagina-} ceae) in Greece. [Phytotaxa, 240, ISSN 1179-3155 (print), 1179-3163 (online).] - Magnolia Press, Auckland, 2016 (ISBN 978-1-77557-859-8 (paper), 978-177557-860-4 (online); doi: dx.doi.org/ 11.11646/phytotaxa.240.1.1). 212 pages, 100 figures (86 drawings, 14 maps), 3 black-and-white photographs. [Received January 2016].

Limonium, or rather, L. subg. Limonium in particular is known as a taxonomically critical group. The main reason for its complexity is the coexistence of mostly diploid, sexually reproducing populations of usually self-incompatible plants (with a peculiar kind of distyly through combined stigma-pollen dimorphism) with what are in effect clones of agamospermous plants of triploid or higher ploidy level. The situation is comparable with what we find in Taraxacum, with a mosaic of variable sexual populations and invariable, apomictic clones of usually hybrid origin. For want of a better alternative, taxa of both categories are cur- 
rently treated as species. As is to be expected in a complex that arose predominantly through hybridisation events, character distribution is reticulate and any grouping of species would be arbitrary. In the main area of diversity, the Mediterranean basin, hundreds of species have been described in old and recent times. In most areas of the Mediterranean Limonium is by now believed to be reasonably well studied and understood, Greece being the single major exception. This was yesterday. Thanks to this book, it no longer applies.

Of the two authors, Matthias Erben is the recognised Nestor of Limonium systematics, whose work up till now was mainly focused on the West Mediterranean area. Salvatore Brullo has many interests beside Limonium, having a well earned reputation of keen observer and often radical splitter. The combination of these two in an author team lends credibility to the published results. Brullo and his crew have done much of the collecting on which the present treatment is based, and the main set of their specimens, supposedly consisting of "several thousand" herbarium sheets, is deposited in Catania (CAT). That figure has obviously been inflated, perhaps under the influence of the Mediterranean sun, because the CAT specimens cited here are "only" about 500 still quite an impressive total.

So far, the only part of Greece in which Limonium had been well studied, mainly thanks to the work of Rea Artelari of Patras University, was the west: the Ionian coast and islands. For the major part of the Aegean coastlines, several stray contributions had been published. From the 15 Limonium taxa recorded in Boissier's Flora orientalis from Greece the number had thus gradually risen to perhaps 40 or 45 . Thanks to this book, in which 39 species are described as new and two former varieties or formae raised to species rank, that number has almost doubled. The 85 species now recognised are treated in considerable detail, with thorough descriptions, full specimen citations, and maps, each being illustrated by Brullo's own drawings.

The material worked through by the authors, as documented by their specimen lists, is certainly impressive, as is the enumeration of no less than 28 consulted herbaria, public and private. However, one should not be led to believe that all extant material has been studied. In particular, neither of the Athens herbaria (ATH, ATHU) have been consulted, and of the Patras Herbarium (UPA), as of many others, only the types and selected critical specimens were seen. A major shortcoming is the authors' failure to work through the exceedingly rich Aegean collections in Lund (LD) assembled by Hans Runemark and his team, among which further novelties likely await recognition. Unearthing them is made easier now, this book providing the key.

W.G.

6. Jean-Pierre REDURON, Walter Karl ROTTENSTEINER \& Christian SCHEUER - Beiträge zur Flora von Istrien V: The Istrian Apiaceae: a new determination key, distribution maps, and a list of specimens housed in the herbarium GZU. [Fritschiana, 81, ISSN 1024-0306.] Institut für Pflanzenwissenschaften, KarlFranzens-Universität, Graz, 2016. 80 pages, 181 figures (grayscale photographs and maps), map; paper. [Received June 2016].

As is apparent from the subtitle, this booklet has a dual scope. On one hand it includes the enumeration of the Umbelliferae holdings of the Graz University Herbarium, 550 sheets in total, thereby complementing Reduron's ten prior papers or notes on Istrian umbels, published in the journal Carinthia between 2002 and 2012. On the other hand it presents a synthesis of our present knowledge of the family in Istria, with determination keys (including diagnostic descriptions) for its 161 non-hybrid taxa 
(species, subspecies, and varieties). Small distribution maps are provided for all of them, indicating their presence and abundance in each of Istria's 21 territories.

Revision of the Graz materials proved particularly rewarding, as it included no less than 10 taxa not previously recorded from Istria and/or the individual countries (or regions) of which it consists: Italy (with Friuli-Venezia Giulia), Slovenia and Croatia. Each of these additions is documented by the photograph of a representative herbarium specimen.

W.G.

\section{Juan Antonio Devesa Alcaraz -} Las especies del género Centaurea en la Península Ibérica y Baleares. - UcoPress, Universidad de Córdoba, 2016 (ISBN 978-84-9927-219-1). 439 pages, numerous colour photographs, maps and drawings, some graphs and tables; hardcover. [60€; received October 2016].

Together with its companion, the Centaurea treatment in Flora iberica published in 2014 (see OPTIMA Newslett. 42: (6). 2015 , for a brief review), this portly volume synthesises much of Juan Devesa's (with three of his pupils') botanical endeavours along his busy academic career. The two works are very unequal twins indeed. On the one hand we have a rigorous, learned presentation in the best style of modern Flora writing, for which Flora iberica is perhaps the most outstanding current example; on the other hand we now look at a work designed to be enticing, not merely useful, to the professional plant taxonomist and the expert layman alike. Unrestrained by the rigour of editorial standards as are indispensable for a Flora, Devesa has here been able to deploy his skills as a botanical writer. Yet he remains a systematist at heart. His book is exemplary by the coherently structured, logical way in which the information is presented. At no point does the user feel lost among the wealth of diverse data. So let me try and be coherent myself, explaining what the user of the book may expect to find.

The title defines the subject accurately: the Centaurea taxa (species and subspecies, with cursory mention of a few varieties) growing in the wild in peninsular Spain and Portugal plus the Balearic Islands: 94 species and 32 additional subspecies, adding up to 126 taxa, of which about two thirds are endemic to the said area. Centaurea, as here defined, is thus the most diverse nonapomictic genus of the Ibero-Balearic flora, preceding Carex, Festuca, and Silene, in this order. Generic delimitation in this group has changed considerably over time, and the twelve sections recognised in Flora iberica, and by consequence here, are phenetically defined and thus definitely not the final answer. Two of them, each with its own pollen type, are natural monophyletic units, each equivalent to the total remainder of the genus; of which at least one, being easily recognisable, and perhaps both, might better be treated as genera (Cyanus and perhaps Colymbada). The other ten, on the contrary, do not for the most part represent natural units, and their species should be regrouped in perhaps half a dozen monophyletic sections. Devesa's choice of classification does, however, conform to tradition; at least for the time being, it is adequate for practical purposes.

The book is comprised of four main chapters of decreasing comprehensiveness. The first acquaints the reader with the plant world of the Iberian peninsula (oddly without the Balearic Islands), and is remarkable among others by including a concise account of its palaeogeography and vegetation history. The second introduces the Compositae family, its affinities as well as its main morphological and biological traits. The third chapter defines the "tribe" here designated as Cynarocephalae, with its main subdivisions, then gives ample space to a general presentation of Centaurea itself with its twelve "sections", with enumeration of 
the taxa recognised in each. After which, thus adequately introduced, follows the last chapter and core portion of the book, with the presentation of the individual taxa preceded by an illustrated key for species identification. The key leads are about the only morphological information provided. The taxon treatments consist of scant text, mostly on distribution and habitat; only for subspecies (absent from the key) are some diagnostic features mentioned. Synonymy is all but absent, so that the reader must necessarily consult the Flora iberica treatment in parallel (the reverse being equally commendable). Almost the whole space is used for illustration: colour photographs (mostly close-ups of flower heads, occasionally showing the whole plant), distribution maps (dot maps on coloured background showing relief traits), and drawings.

The photographs will be seen as the most appealing element of this volume. This applies, not only to those that appear in the taxonomic treatment proper but also to those in the three preceding chapters. All are of excellent quality and remarkable beauty, and almost all (with specified exceptions) are by Devesa himself. As to the drawings, they have for a considerable part been published elsewhere previously, most of them in Flora iberica. They have been made especially for the purpose of this book's subject, under Devesa's direct supervision, and are all by the same artist: a Mexican resident in Sevilla, Rodrigo Tavera. [Do not be confused by the signatures that appear on the plates, rarely mentioning explicitly Rodrigo but usually only with the initials TM plus "Triana" or "Sevilla", plus the year: TM stands for the artist's full name, Talavera Mendoza; the remainder are place names, Triana being a borough of Sevilla.] These plates of drawings, which in addition to the habit include accurate magnified details of the flower heads, corollas, anther tube, cypsela, pappus and stylar apex) are a unique and, in its completeness and consistency, uniquely valuable asset of the book.

Preface matter, while often well written and always well meant, is not usually worthy of mention in a book review. Let me make an exception and pay a compliment to José Carrion for his excellent introductory text, which includes some personal notes on Devesa's life and merits that are well worth being told in this very place. W.G.

\section{Paolo Grünanger, Bruno Barset- TA, Francesco DE GIGLIO, Egidio Trainito \& al. (ed.) - Orchidee} d'Italia. Guida alle orchidee spontanee. Seconda edizione. - Il Castello, Cornaredo, 2016 (ISBN 978-88-6520-801-4). 368 pages, numerous photographs (mostly in colour) and maps, drawings, graphs, tables; laminated cover. [24€; received April 2016].

Published under the auspices of GIROS, the Italian Research Group on Wild Orchids, this is a book of high status among Italian orchid lovers. The first edition, published 7 years ago, was reviewed by me rather critically (see OPTIMA Newslett. 39: (4-5). 2010). The second edition, which on the cover (but not on the title page) is qualified as "interamente aggiornata" (completely updated), has been substantially improved. The amount of change can be inferred from increase in almost every respect: number of text authors (from 40 to 45), of authors of photographs (32 to 57), of pages (303 to 368), of accepted taxa (193 to 230). Only the selling price, hear! hear!, has remained the same.

The introductory chapters, which I had deemed to be excellently suited to their purpose, have changed but little. A new text on Ophrys pollination biology, and a third author (Alessio Turco), have been added to the chapter on orchid biology; and a chapter on conservation (by Sara Magrini and Simon Pierce) has been inserted, focusing on 
germplasm banking and in vitro propagation techniques in addition to in-situ protection. The main improvement is in the core of the book, where all taxa known to be present in Italy are presented. This part is better structured now than it was before. Keys for species identification have been provided for all genera except Ophrys and Epipactis; and in the latter two genera, where taxon limits are blurred and differences minimal, the treatment at least is preceded by an illustrated synopsis that includes mention of the main diagnostic features. In Ophrys some of the local variants that had been recognised as species have thankfully been reduced to subspecies rank, even though, perhaps inevitably, the splitting is still excessive. In Epipactis, a genus plagued by totally or partly autogamous "microspecies", the number of recognised species has increased from 16 to 27 , but the number of taxa rose only by 3 . In Nigritella, taxon number has diminished (from 12 to 8 ) but species number, conversely, exploded from 3 to 7 . Orchidologists are well known to adore change, both in taxon circumscription and in nomenclature, and here they are well served. In my opinion, though, this time the changes - at least the name changes - are for the better.

There is a welcome innovation in this edition that I must not forego mentioning: on erratic pages, Italian "orchidologists" (meaning: botanists who described and named some orchid) are presented, in portrait and biographically. These are most useful, well written and informative texts which I can but commend. Inexplicably they are not indexed, and impossible to find except by chance. I shall therefore list them here in alphabetical order, followed by the relevant page number: Bertoloni (123), Bianca (277), Bivona (71), Cirillo (73), Cupani (32), De Notaris (326), Mauri (219), Moretti (213), Parlatore (344), Scopoli (55), Tenore (187), Tineo (247), Todaro (348), and Viviani (103).

\section{Floras}

9. Daniel Jeanmonod (ed.) - Compléments au Prodrome de la flore corse. Asteraceae - IV: Hieracium, Pilosella et Taraxacum, par Jean-Marc TISON, Jan ŠTĚPÁNEK, Jan KIRSCHNER \& Daniel JEANMONOD. - Conservatoire et Jardin botaniques, Ville de Genève, 2015 (ISBN 978-2-8277-0819-2). 323 pages, 70 black-and-white figures (maps and drawings), 20 plates of colour photographs; laminated cover. [45 CHF; received January 2016].

John Briquet, were he still among us, would be overjoyed: one-hundred-and-five years after he started publishing his monumental, critical inventory of the Corsican flora known as the Prodrome, it has been completed. Even for a work of that size and complexity such a time scale is unusual, and indeed, to be exact, it is not the Prodrome itself but its reincarnation in the form of complementary treatments, launched 30 years ago, hat has reached the final goal; the hero being, no longer Briquet but Daniel Jeanmonod, his dignified successor as editor and principal author of the series. Congratulations, Daniel!

The concluding $4^{\text {th }}$ portion of the Compositae family, a sort of dessert, differs in many respects from its forerunners (see OPTIMA Newslett. 41: (8). 2013). It comprises the treatments of three genera that are foremost among the "bad boys" of the European flora, each in its way and due to its own, peculiar anomalies of reproductive system and speciation mode: Hieracium, Pilosella (both authored by Tison), and Taraxacum (by Štěpánek \& Kirschner, assisted by Jeanmonod).

The most innovative not to say revolutionary approach is that for Hieracium, in which Tison resolutely breaks with the tradition based on Zahn, still followed faute de 
mieux in Med-Checklist. Zahn's two-level classification of taxa into species and subspecies, theoretically ill-founded, is done away with, and the Corsican plants, among which no sexually reproducing diploids are known, are all assigned to agamospecies. One would therefore expect that the number of species here recognised be much higher than the 19 known from Corsica to Zahn, approaching the total of ca. 100 taxa recorded from the island by that author; and one will marvel when finding the identical number of 19 accepted species, discounting three recently observed casual aliens. The reason is twofold. First, no less than 43 taxon records proved upon inspection of the specimens to be errors; and second, the agamospecies as here defined are to some degree variable, due to phenotypic plasticity and accumulation of mutations over time, so that they may include plants formerly assigned to several different taxa.

For Pilosella, where Tison follows in essence the Med-Checklist precepts, the result is similar. Of the 12 species previously reported from Corsica only 6 remain, two of them newly raised in rank; the remainder having either been excluded as corresponding to misidentifications or synonymised under a somewhat more generous species concept. In partial compensation for these "losses", two new interspecific hybrids are described and named.

Finally, the Taraxacum account brings no great surprise. It recognises 27 species (one unnamed due to lack of adequate material) in 9 sections, plus a $10^{\text {th }}$ section, $T$. sect. Taraxacum, with an indiscriminate number of weedy species which not even the authors, keenest among taraxacologists, dare to distinguish or name - a failure that other, less experienced botanists may be soothed to note. The arguably most revolutionary innovation, here, is the introduction of the new concept and term of nomina damnabilia. The suggestion is that names published with too lousy descriptions and based on material too poor for reliable identification be "cursed", or put into quarantine, at least until someone - preferably the guilty author - comes up with a more adequate description and type specimen. One wonders whether a proposal is forthcoming, to embody that notion in the International Code of Nomenclature. W.G.

10. Pier Virgilio ARrigonI - Flora dell'isola di Sardegna, 5. - Delfino, Sassari, 2015 (ISBN 978-88-7138-642-3). 575 pages, 175 plates of drawings or in facsimile; laminated hardcover. [Received November 2015].

11. Pier Virgilio ARrigoni - Flora dell'isola di Sardegna, 6. - Delfino, Sassari, 2015 (ISBN 978-88-7138-790-1). 540 pages, 188 plates of drawings or in facsimile; laminated hardcover. [Received November 2015].

The initial plan of this Flora has taken over 30 years to mature, but once Arrigoni got started he worked at remarkable speed. Within nine years (2006 to 2015) all six volume have been published, the two last ones simultaneously last summer. Congratulations, Pier Virgilio, on this feat and happy end. You have contributed an important item to the growing number of basic modern Floras of Mediterranean areas.

Volume 5 comprises the last part of the dicotyledons (Compositae plus three smaller families) and the beginning of monocots ("Liliiflorae" families and orchids), vol. 6 the remaining monocots (aroids to Commelinaceae, including the aquatic groups, and the "Glumiflorae" families). Data presentation has remained remarkably uniform throughout the six volumes, so that little needs to be added here to what I have written on previous occasions (see OPTIMA Newslett. 38: (19-20). 2008; 40: (7-8). 2011; 42: (8). 2015). As before, the illustrations are an important asset. Apart from some 
reproduced from the classical literature, Moris's Flora sardoa in particular, and a good number taken from recent papers (Arrigoni's own and those of, e.g., Ignazio Camarda and Franca Valsecchi, who are themselves consummate botanical artists), the drawings here presented, usually with analytical details, were unpublished to date. Indeed, one of the Flora's most valuable features is the abundance of original artwork, all contributed by excellent botanical illustrators - Anne Maury (omnipresent), G. Bernetti (most grasses), A. Mazzanti (sedges in particular), B. Buonarroti, and L. Bindi who, one infers from the accuracy of every detail, were working under the author's immediate supervision.

The final volume ends with a cumulative generic index for the entire work, preceded by an inventory of taxa endemic to the Tyrrhenian islands. There also a substantial portion of addenda and emendanda, with two dozen additional taxa recently reported, confirmed, or described as new. One might have wished to find an overall bibliography or list of references but is disappointed, presumably because the short, sometimes cryptic, occasionally absent source indications in the body of the books are deemed sufficient. One item that is definitely lacking is a family key for Angiosperms, such as had been provided in volume 1 for the Pteridophytes and Gymnosperms. W.G.

12. Arne STRID - Atlas of the Aegean flora. Part 1: Text and plates. Part 2: Maps. [Englera 33(1-2). 2016; ISSN 0170-4818]). - Botanic Garden and Botanical Museum, Berlin, 2016 (ISBN 9783-921800-97-3 \& 978-3-921800-98-0). $700+878$ pages, 48 plates of colour photographs, $4+3362$ maps, graphs, colour photographs, tables; two hardcover volumes. [120 €; received April 2016].
This sizeable and weighty opus is more than a chorological atlas of the Aegean vascular flora, as the title might make believe. It is also a complete Flora, with keys, short synonymies, descriptions, and critical notes in the first (text) portion, and with indication of habitat and general distribution in the caption of the maps, in the second portion. It is therefore a worthy successor to Rechinger's classical Flora aegaea of 1944, but differs from it in many important features. To draw a comparison: Flora aegaea lacks taxon descriptions and indications of general distribution; instead of distribution maps it includes literature references and specimen citations under each taxon; it covers nonvascular plants and the Turkish Aegean islands as well as the Turkish and Greek peninsulas extending into the Aegean Sea. Neither work has a family key or keys to genera, neither deals with nomenclatural types, and both tacitly include the (nonAegean) Greek Kastellorhizo island group.

The maps have been produced directly from Strid's Flora Hellenica Database, with one positive and one negative consequence. On the positive side, they extend beyond the Aegean islands proper to the north and west, to encompass the whole Chalkidiki peninsula, Mt. Pelion, as well as most of Attica, Argolis, and the Malea peninsula (of course only for those taxa that occur on at least one Aegean island as well). Conversely, the two Aegean islands belonging to Turkey as well as the West Anatolian coastlands, not being represented in the database (not, as the introduction pretends, due to "scarcity of data"), are left off the maps. "Left off" is to be understood literally, in that the Turkish coastline, where it should appear on the mapped square, was simply erased, which leaves the offshore islands in the East Aegean as curiously isolated in a vast expanse of sea.

I have tried out this Flora repeatedly and found it to be well written, complete, accurate, and carefully edited, with due re- 
spect for the practical needs of the user. The latter trait is obvious in such trivial details as family names appearing in the running title on each page: a most commendable (even though not generally fololowed) practice when, in a book, the information is given by alphabetically arranged, and somewhat idiosyncratically defined, families. One feature that is missing is a page reference to the relevant text entry in each map (the reverse reference does exist). W.G.

\section{Popular Books}

13. Giuseppe CARUSO - Andar per piante tra terra e mare. Escursioni botaniche sulle coste della Calabria. - Koeltz Scientific Books, Königstein (Taunus), 2015 (ISBN 978-3-87249-483-6). [2] + 460 pages, 388 figures in colour (photographs and maps), 8 tables; laminated hardcover. [58€; received September 2015].

In essence, Caruso's book is a popular guide to the plant world of a given region; but as such it is unusual in several respects, to begin with its uninformative title. "Going for plants between land and sea" suggests a botanist's hike along the shoreline. Which is wrong. First, it is not just the shoreline we are asked to contemplate, it is a full belt of costal vegetation, dunes, marshes and cliffs; second, as the subtitle discretely informs us, the scenery is not set just anywhere but is a finite portion of the Mediterranean coast: the tip of the Italian boot, Calabria; and finally, truth be told, the sea hardly comes into the picture except as backdrop: no mermaids, no seaweeds, not even a bit of a seagrass - land alone matters.

The book's central portion is meant for use in the field. It suggests 25 excursions to worthwhile target areas, complete with detailed itineraries, a route map, mention of plants, and photographs of the botanical landscape. The recommended sites are unevenly spaced all along the Calabrian coastline, wherever still unspoilt areas exist. This section is followed by a set of 207 plant portraits, each with a short description and colour photograph; and it is preceded by general chapters on the geomorphology, climate and plant cover of Calabria as a whole and on the biota of the coastlands in particular, with emphasis on the threats currently faced by what is still left of them.

Caruso is a naturalist at heart, and as such he is distressed when seeing greedy or thoughtless humans, with the blessing of politics, wreaking havoc on his homeland's natural heritage. This book is an anguished cry, a desperate plea for to putting hold to this process. But will those responsible bother to note? The author himself doubts it, he calls for a new cultural awareness of people, local people in the first place, to bring about a change of attitude of who is in charge.

This is perhaps the crucial question: for whom has this book been written? I dare say, for the author's own sake in the first place; which is not necessarily a bad thing, because texts written in that mood are usually - as is the case here - not only instructive but fascinating to read. Yet some more regard for the reader's legitimate needs would have been in order, e.g. by the provision of sensible indexes. There are indexes for sure, but they are unhelpful and, worse, incomplete. There is no subject index. The index of Latin names refers only to the formally treated and alphabetically arranged taxa and therefore gives no page numbers - but the same and many additional taxa are mentioned, and sometimes illustrated, elsewhere in the text, where they cannot now be found. The Web links provided in that index for a selection of the not formally treated taxa would be a commendable extra, were this an electronic publication; but how many will have the patience to type lengthy strings of alphanumerical garbage into his computer to 
obtain relevant information? Also: using state-of-the-art plant names looks good, but may cause problems when species arrangement follows the alphabet. Who except the consummate freak will look up Putoria under Plocama, Hedysarum under Sulla, or Otanthus (which he has just learnt to prefer to Diotis) under Achillea? True, the still familiar synonyms are listed, but this does not help as synonyms are, on principle, not indexed.

Some sound editorial advice to the author, obviously not an expert writer yet, would have done this book a lot of good and benefited its readers. Even so, it is my wish that these readers be numerous - and be convinced to carry over the message it is meant to convey.

W.G.

\section{Edwin LANFranco \& Guido BonetT} - Wild flowers of the Maltese Islands. [Nature Guide Series.] - Book Distributors Limited, [San Gwann, Malta], 2015 (ISBN 978-99957-46-59-9). 208 pages, numerous colour photographs; laminated cover. [15 €; received January 2016].

There are many well illustrated wildflower books for Mediterranean countries on the market, even a few for the Maltese Islands. The present one, which stands out by the good quality of its illustrations and high standard of scientific reliability, commendably lists a fair selection of similar and partly competing recent titles at the end. Almost 300 members of the native and archaeophytic flora of Malta, excluding trees but adding a few fully naturalised recent arrivals, are here presented in text and image; several more are briefly mentioned under their closest resemblance or relative. In a not very diverse flora like Malta's this makes up for over one third of the wild flora, and as the common and/or eye-catching plants have been selected in preference, the authors' claim is reasonable, that their book "should enable one to name a fair proportion of wild plants growing in Malta". The text author, Lanfranco, drawing on his lifelong experience of high-school and university teacher, has been careful to use simple if scientifically accurate language, the few unavoidable technical terms being explained in a glossary. A rather uncommon, valuable feature is the care taken in selecting (and when necessary coining anew) appropriate common names, both in Maltese and English. The book, its reasonable price aiding, will no doubt be in high demand. W.G.

\section{Regional Studies}

\section{Josep E. Oltra I Benavent \& Anto- ni CONCA I FERrús - Plantes vascu- lars del quadrat UTM 30S YJ21 Be- nigànim. [ORCA: Catàlegs floristics lo- cals, 19.] - Institut d'Estudis Catalans, Secció de Ciències Biològiques, Barce- lona, 2015 (ISBN 978-84-9965-282-5). 91 pages, maps, graphs; paper. [Re- ceived May 2016].}

Three years after $\mathrm{N}^{\circ} 18$ (see OPTIMA Newslett. 41: (14). 2013), here comes the next item in ORCA's series of local floristic inventories, each devoted to one unit square of the Catalan mapping grid. The area covered lies in the southernmost portion of Catalunya, halfway between Valencia and Alicante. Three villages (Benagànim, Quatretonda, and Llutxent) are included, all situated in the southern half of the square, in lowlands of Miocene marls. The northern half is comprised of a chain of limestone hills (Sierra de Solana and Sierra de Portlitxot) culminating at $629 \mathrm{~m}$ of elevation. Climate and vegetation are basically Mediterranean. Cultivated ground and wasteland predominate. Few remnants of the potential oak wood vegetation subsist in a degraded state. By consequence, the vascular flora is rather trivial and, in spite of the presence of a con- 
siderable number of alien, introduced species, not very diverse: 955 taxa (species and subspecies) plus 7 hybrids are listed. W.G.

16. Dêmêtrios FoITos, Georgia KAMARÊ, Nikê KATSOUNÊ \& Geôrgios MÊTSAINAS (ed.) - To oros Ainos tês Kefalonias. Istoria, fusiogeôgrafia, biopoikilotêta. - Foreas Diaheirisês Ethnikou Drumou Ainou, Kefalonia, 2015 (ISBN 978-960-9407-30-4). xvii + 333 pages, 213 illustrations (mostly colour photographs), two extra foldout colour maps; hardcover with dust jacket. [Received April 2016].

Mount Ainos (pronounced Enos) is the highest mountain of the Ionian island of Kefallinia (Cephalonia): a long, north-tosouth oriented ridge in the island's southeastern part, which culminates at $1627 \mathrm{~m}$ in Mt. Mega Soros (the big stone heap, aptly so named). It draws its fame principally from the large forest of Greek fir, Abies cephalonica, a tree that was originally described from there. Today the higher portion of the range, including the entire fir wood, is protected as a National Park and, as such, is very popular among Greek and foreign nature lovers. This splendid and informative book is written for them. Its initial chapters are devoted to the mountain's (and island's) history, including classical and archaeological sources, and to physical geography. Other, richly illustrated parts deal with the vegetation, the vascular flora (with emphasis on the local and regional endemics and with a large section on orchids), the fungi, and the fauna. Illustration is generous and of superb quality. The texts, for who is familiar with modern Greek, are well written and informative (there is an extensive list of literature references at the end of each chapter). The only English phrase I was able to spot in the whole book is in the (bilingual) caption of the photograph on the cover inside - but perhaps, subject to availability of funds, may we hope for an English edition? W.G.

\section{Excursions}

17. Ina DINTER - Insel Rhódos, EAe (Gr). Botanische Studienreise vom 21. April 3. Mai 2015. Exkursionsbericht. - Privately assembled/printed, Ostfildern, 2015. IV + 51 pages + CD-ROM, map, graphs, colour photographs, tables; paper, plastic front cover sheet. [Received August 2015].

For the general scheme and layout of Ina Dinter's excursion accounts, see e.g. OPTIMA Newslett. 41: (15-16). 2013. The above item relates to a group excursion to the island of Rhodes, at the SE corner of the Aegean archipelago, under the author's expert leadership. As the group members are for the most part inveterate disciples of Ina Dinter who are coming into their years, the programme was physically less demanding than on former occasions. A beach resort just west of the city of Rhodes was chosen as the excursion's single base, and hired cars were used for the trips, ensuring increased mobility. About 20 localities were visited, all around the island's perimeter and also in the interior, and plant lists are here included for 16 of them, with mention of voucher specimens (in Dinter's private herbarium) and photographs, if any. A selection of plant portraits and landscape pictures is documented in the attached CD-ROM. As usual there is a consolidated plant list at the end of the text, which however, regrettably, this time lacks the customary reference to the corresponding individual localities.

W.G.

18. Ina DinTER \& Reiner ZiMmERMANN (ed.) - Norden der Insel Zypern. Botanische Exkursion. Institut für Botanik, 
Universität Hohenheim, Stuttart,13.-24. März 2015. Exkursionsbericht. - Universität Hohenheim, Stuttgart, [2016] (ISBN 978-3-00-052073-0). VII + 129 pages, 262 figures (colour photographs, maps, graphs), 16 tables; paper. [Received February 2016].

This account relates to the newer kind of Ina Dinter's excursions: student field courses, led by her as a lecturer of the Stuttgart-Hohenheim University (see also OPTIMA Newslett. 42: (12-13). 2015). It is thus an official publication of that University. Most daily or half-daily accounts of the report were written by the students themselves, 15 in number, to which 10 senior participants plus the leader must be added: a sizeable group indeed. Dinter herself is the author or co-author or several chapters and of a number of plant portraits disseminated throughout the text, indexed on p. 124. In all, over 320 plant taxa were found and many of them photographed (but none collected). They are listed separately for each locality and again in a synthetic table at the end.

As is the rule of Dinter's many excursion reports, botany is only part of the menu, which includes aspects of the visited country's culture, architecture, archaeology, landscapes, and animals. The present report is particularly well illustrated. For Germanspeaking visitors, it offers itself as a valuable complement to the available Floras and wildflower books. As long as the stock lasts, copies can be obtained from the main editor (ina_dinter@uni-hohenheim.de). I have found no price quoted.

W.G.

\section{Conservation Topics}

19. Virgile Noble, Jérémie VAn Es, Julie Delauge, Dorothée Meyer \& Céline HAYOT (ed.) - Liste rouge régionale de la flore vasculaire de Provence-
Alpes-Côte d'Azur. - Le Naturographe, [Gap], 2016. [2] + 20 + [2] pages (including cover sheet), colour photographs, graphs, tables; paper. [Received June 2016].

Provence-Alpes-Côte d'Azur (PACA) is one of 22 administrative Régions of France, situated in the countries SE corner and comprising 6 of the traditional Départements, from Bouches-du-Rhône east to HautesAlpes and Alpes-Maritimes. With about 3400 vascular plant species, including 31 strict endemics, it is one of the floristically richest areas of France and indeed Europe. The SW Alps are of particular phytogeographic interest, being considered as the area where much of Europe's plants have survived the last glaciation, and still home to many old relict species. The present account is enlivened by colourful photographs of a small sample (13species) of PACA's flora.

The present "red list" enumerates in tabular form those species and subspecies that are considered to be threatened or extinct on the PACA territory, grouped by relevant IUCN threat categories: RE (regionally extinct: 26 species +1 subspecies), CR (critically endangered: $49+6$ ), EN (endangered: $118+7$ ), and VU (vulnerable: $200+24)$. This means that $11.6 \%$ of the native vascular species are rated threatened or extinct, a percentage that is due to increase when the data-deficient taxa, not yet evaluated, can be included in the analysis.

W.G.

20. Dimitar Peev, Antoaneta S. PetroVA, Mincho AnChev, Dobrina TEMNISKOVA, Cvetomir M. DENCHEV, Anna Ganeva, Chavdar Gussev \& Vladimir Vladimirov (ed.) - Red data book of the Republic of Bulgaria. Volume 1. Plants and fungi. - Bulgarian Academy of Sciences \& Ministry of Environment and Waters of Bulgaria, Sofia, 2014 (ISBN 798-954-9746-21-1 \& 
798-954-8497-17-6). 881 pages, illustrations (most in colour) maps, 1 table; hardcover. [Received June 2016].

The precursor, or first edition, of this book was published in 1984 in Bulgarian, with title Červena kniga na NR Bălgarija (see OPTIMA Newslett. 17-19: 69-70. 1985). At that time it was a pioneer achievement, one of the early national Red Data Books, indeed the first to be published for a country of the Mediterranean region. It is worth mentioning that the general design of the book was so far-sighted that it was not necessary to alter it radically after thirty years. Of course, some changes are apparent: threat categories have been adjusted to the current, IUCN-defined international standards; data in the (now English) text have been expanded and the map enlarged, with the result that one rather than two species are presented on each page; algae (6), bryophytes (102), and fungi (149) have been included, each with its own reference list; the arrangement is no longer taxonomic but alphabetical within each threat category (not really an improvement). All illustrations are new, mostly colour paintings by Dimitar Vlaev (colour photographs for many algae and bryophytes, drawings for two algae). Page number has almost doubled.

Limitations of space and funding have regrettably resulted in less complete coverage than was possible in the first edition. For vascular plants, only549 taxa instead of the former 763 have been treated - a $28 \%$ decrease. The difference affects plants of the "vulnerable" category, of which only a small selection could be taken on board. Nothing is said on the criteria for that selection, nor has, regrettably, a complete list of threatened (including vulnerable) taxa been provided. Such a "red data list" does however exist (prepared by Petrova \& Vladimirov in Phytol. Balcan. 15: 63-94. 2009; similar lists for bryophytes and fungi were produced separately).
A question to which one hopes to find an answer here is: how has the situation, for vascular plants, evolved in the 30 years since the first edition appeared? What are we told, in particular, with respect to extinction? In 1984, 31 taxa were considered to be extinct in Bulgaria, one of them a global extinction (Hypericum setiferum, known only from the type gathering and of uncertain taxonomic value). In 2014 the number has decreased to less than half: twelve regional extinctions and two global extinctions (the single known tree of Quercus thracica, a hybrid or variant of $Q$. cerris, having died of disease or old age by 2009). Does this mean that the situation is less alarming now than it was before? Not really. Rediscovery of some previously disappeared plants and dismissal of others that had been recorded in error explain the apparent decrease. Conversely, five species formerly listed as threatened are now rated extinct: Lycopodium complanatum, Dracocephalum thymiflorum, Herminium monorchis, Lathyrus transsilvanicus, and Quercus thracica. But again: if you look at the dates, you find that for three of the plants disappearance is not recent: they were last seen in 1934 or even before. We are left with a single case of recent extinction, Dracocephalum, last observed in 1989. All in all, the situation of the Bulgarian vascular flora is less dramatic than one might have feared - for which Bulgarian botanists, including the present authors, may take part of the credit. The announced online publication of an expanded version of the book will no doubt enhance its beneficial impact on public opinion and policy makers.

W.G.

\section{Bibliography and Biography}

\author{
21. Gerhard WAGENITZ \& Hans Walter \\ LACK - Carl Ludwig Willdenow, ein \\ Botanikerleben in Briefen [Annals of
}


the History and Philosophy of Biology, 17: [10] + 1-289 (ISSN 1863-0197)]. Universitätsverlag, Göttingen, 2015. 8 figures (facsimiles); paper [journal volume; no reprint seen]. [Received March 2016].

The interest of this essay for historical botany in general may justify its presentation, although it is neither an independently issued work nor is it particularly relevant to Mediterranean plant studies. As a botanical author, Carl Ludwig Willdenow, also surnamed the "Prussian Linnaeus", is familiar to all botanists. This is not the first learned text written on him, but shows an original approach that makes it particularly attractive: it presents the man and botanist Willdenow as he appears through the letters written by him to others.

Not as easy a task as it might seem, and one involving a considerable amount of sleuthing. To begin with, of the letters written by others to Willdenow virtually nothing has survived (the exception being a few written by Alexander von Humboldt, one of which also transcribed here). The authors had to be content in showing one face of the medal - and how to find it must not have been an easy task. Starting from the holdings of Willdenow's herbarium and, from there, concluding who the likely correspondents might have been, they were able to find 156 of Willdenow's botanical letters, scattered through the state and institutional archives of Europe and America. Curiously (and regrettably) they tell little of the search itself, they even fail to give an overview of the consulted repositories (which are mentioned only under the individual, chronologically arranged letters).

Otherwise, the essay is not only suitably indexed and easy to consult, it is also exemplary in placing the biographically and botanically relevant data into an historical and political context. Thereby, an overall picture arises of that important part of European culture of the time that was correspondence among peers. It makes one wonder what will one day happen with our current, even more widespread and intense electronic mail network, so marvellously easy to handle, search and organise - yet so desperately fragile an ephemeral. Will we be able to create structures for conserving at least some of it before it becomes irredeemably lost? Our life, it sometimes appears to me, happens in an historical vacuum, so no one cares. But others might come after us, one hopes, to rediscover the time dimension of our being.

Sorry for having gotten off track. What remains to be said is that the paper at hand includes aspects one would not necessarily expect under its title: a complete bibliography of Willdenow's scientific writings, scattered through several journals; extracts from the personal friendship album of Willdenow's youth; and notes on the subsequent fate of his herbarium and library, with suggestions for further investigations on the missing avascular plant collections. A wealth of potentially useful and largely unknown information, brought to light by two botanists with a shared interest in Willdenow who also happened, each in his turn, to supervise the Berlin-Dahlem library and Compositae collections. W.G.

22. André Charpin \& Gérard-Guy AYMONIN $\uparrow-$ Botanistes de la Flore de France. Notices biographiques [ed. 2]. [Le Journal de Botanique, hors-série 2015 (ISSN 1280-8202)]. - Société botanique de France, 2015. 197 pages, numerous figures (portraits), 1 colour plate; paper. $[25 €$; received April 2016].

Early in 2000, Aymonin \& Charpin published their Bibliographie sélective des Flores de France as issue 10 of the Journal de Botanique (see OPTIMA Newslett. 36: (42-43). 2002): an inventory of floras and 
floristic papers published between 1753 on vascular plants of the French homelands (excluding the overseas depertmenrts). A second part of the Bibliographie, with subtitle "Notices biographiques sur les auteurs cités" and authored by Charpin \& Aymonin, appeard in 2003 and 2004, in four instalments, in the same journal. The present book is its consolidated, corrected and expanded second edition.

This is not, as a hasty glimpse at the title might make believe, a biographical compendium of French botanists. First, you need not be a botanist to be admitted, as a foreigner you qualify just as well, provided you have published a book or paper on the French flora; second, you must have published, just knowing the plants and assembling a herbarium won't do; third, vascular plants only count; and fourth, you must have been dead since at least 2002 (coverage of the present edition has apparently not been expanded to later casualties). If you fulfil these criteria you may be pretty sure to find yourself mentioned, with places and dates of birth and death officially certified by the competent municipal and departmental registers, of which scores have been consulted by the authors to establish or authenticate the data.

The second edition, while more practical to use, also offers two novel aspects. Firstly, it is enriched by a large number of portraits, many of them unpublished before: engravings and photographs have been used liberally, most of them kept in the archives of Geneva's Conservatoire botanique. It gives you quite a different, more immediate feeling when you can look at the image of the person alongside with the dry data of his life [a propos persons: disregarding admixtures, all those portrayed are male, with a lone exception: Aimée Camus]. Secondly, a so-called index has been added, listing botanical authors by departments; but that index is so blatantly incomplete as to be virtually useless, and you are better off consulting the original Bibliographie instead. Just think: no regional floras are allowed; Corsica lacks Briquet, Litardière, Bouchard and Marcelle Conrad; and none of Lamarck, Candolle, Grenier, Godron, Rouy, Fournier or Guinochet are acknowledged to have authored a French flora. W.G.

\section{Stefan STANev - Čuždestranni izle- dovateli na bălgsrskata flora $i$ ras- titelnost (do 1944 g.) [Foreign explorers of the Bulgarian flora and vegetation (up to 1944)]. - Universitetsko Izdatelstvo "Pajsij Hilendarski", Plovdiv, 2016. 147 pages, 29 figures (portraits); paper. [Re- ceived July 2016].}

A useful account of 30 foreign botanists who contributed to the knowledge of Bulgarian plants, either by exploring the country themselves or, in some cases, by studying material collected by others. One of them, Ami Boué, is a pioneer of vegetation science, several others made important contributions in the field of phytogeography, but essentially they were collecting and describing (vascular) plants. Three early travellers, Sestini, E. D. Clarke and Dumont d'Urville, are mentioned briefly in an introductory chapter. The others are treated more extensively, with mention of their important floristic achievements including Bulgarian plants first described by them, a list of their own relevant publications, and a bibliography of sources. They are: Sibthorp, Frivaldszky, Boué, Grisebach, Janka, Boissier, Dingler, Pančić, Velenovský, Bornmüller, Vandas, Degen, Podpěra, Zahn, Hayek, Adamović, Turrill, Mattfeld, Novák, F. Hermann, and K. H. Rechinger. A tabular inventory of Frivaldszky's new taxa, with full protologue reference and, as far as possible, specimen provenance will be found to be of particular usefulness. Some other active explorers have been inexplicably left out, such as Formánek.

W.G. 


\section{Names and Nomenclature}

\section{Yusuf Menemen \& Ali A. Dönmez} (transl.) - Uluslararası alg, mantar ve bitki Adlandırma Yasası (Melbourne Yasası), Onsekizinci Uluslararası Botanik Kongresind, (Melborn, Avustralya, temmuz 2011); kabul edilmiş ve J. McNeill, Başkan, F. R. Barrie, W. R. Buck, V. Demoulin, W. Greuter, D. L. Hawksworth, P. S. Herendeen, S. Knapp, K. Marhold, J. Prado, W. F. Prud'homme van Reine, G. F. Smith, J. H. Wiersema, Membri, üye N. J. Turland, Editoryal Komite Sekreteri, tarafindan düzenlenip, yayına hazırlanmıştır. Hacettepe Üniversitesi Yayınları, 2014 (ISBN 978-375-491-406-1). xxxi + 208 pages; laminated flexible cover. [Received July 2015].

The Turkish translation of the English edition of the Melbourne Code, predicted last time (OPTIMA Newslett. 42: (20). 2015), has now been published. The numerous and active Turkish biologists working in plant, algal and fungal taxonomy have no longer a valid excuse for not knowing, and not abiding by, the rules of nomenclature that prevail in their respective groups. They will certainly welcome this new tool, even more important to their work owing to the fact that the Melbourne Congress, in 2011, approved important changes in the rules. Also, in the Melbourne Code an entire chapter, related to the valid publication of names, has been substantially restructured. W.G.

25. Joan Vallès I Xirau, Joan Veny I ClaR, Josep Vigo I BonADA, M. ÀNGELS BONET I Galobart, M. Antònia JULIÀ I BERRUEZo \& Joan Carles Villalonga I Terrasa - Noms de plantes. Corpus de fitonímia catalana. - TERMCAT, Centro de Terminologia, Barcelona, 2014 (ISBN 978-84-3939168-5). 1085 pages +32 extra plates of colour photographs; hardcover. [Received June 2016].

How should botanical nomenclators in common language be organised, what should they look like? This heavy volume pioneers in suggesting good answers to these questions. It is, dare we hope, a good start into a new era of multilingual botanical nomenclature.

The book is a dictionary to plant names in Catalan language that appear in published (including electronic) sources, together with their internationally known scientific, Latin equivalent. It does not result from "field work", meaning the direct inventorying of the usage of common names in local communities, and indeed discards such information unless it has been separately published. Its coverage is not defined geographically, except through the area covered by the used information sources; rather it encompasses any area in which some form of Catalan is spoken, including the region of Valencia, the Balearic Islands, and French territories in the E Pyrenees; nor is it confined to taxa indigenous to those regions, as it takes on board any cultivated (including ornamental) plant that is sufficiently well known to be mentioned in Catalan speech. One clear limitation exists: non-vascular plants are excluded.

Catalan plant nomenclature is just that: nomenclature; and it follows concepts and procedures surprisingly analogous to scientific nomenclature as governed by the International ex-botanical Code: there are accepted names, synonyms of various categories, and homonyms (here termed homophones); potentially, though only by implication, Catalan names have types (the types of the equivalent scientific name) and authorship (the authors of the source works from which they were taken). One even finds names for form-taxa or organ-taxa (referring to special plant parts or life cycle stages)! 
The body of the book thus follows a familiar arrangement. The alphabetically arranged entries are either cross-references to an accepted name (care: "veg." means see, not vegetable) or accepted names, in which case they are followed by synonymy, Latin equivalent, family placement and sometimes notes. Catalan names are assigned gender and number and referenced to selected sources. Three categories of synonyms are recognised (but the scope and criteria for distinguishing them remain somewhat mysterious): normative synonyms, plain synonyms, and linguistic variants (not coextensive with what we would define as orthographical variants), the two former also appearing as cross-referenced entries in the main list, and the two latter (but not the first) being indexed as linguistic variants - a perhaps unnecessary, impractical complication. Otherwise the information is as complete and rationally presented as one might wish. The single item those users not familiar with Catalan (of whom there might be many!) will miss is a guide to correct pronunciation.

The bulk of information in the book is impressive. Administered in a database, over 35000 Catalan designations and some 8400 Latin names have been brought together and referred to 5800 recognised taxa: certainly not an easy undertaking, but it proved to be feasible. A huge step forward indeed - but not yet the final step. The problem of synonymy, in principle at least, has been solved, but homonymy remains. The current approach places no ban on accepting the same designation for more than one taxon, e.g., one genus and more than one of its species (as in ortiga), or even many partly unrelated species (cotó, the accepted designation of 16 species of 5 genera in 3 different families). Unless and until homonyms are disallowed (by synonymising all, or all but one, of those now accepted), Catalan designations will not achieve their potential role as univocal communication vectors. W.G.

\section{Herbaria and Libraries}

26. Piero Cuccuini, Chiara NePI, Mohamed N. AbuhadRa, Lorenzo CECCHI, Helmut Freitag, Egildio LuCCiOli, Maria Maier Stolte, Rossella MArcucci, Lorenzo Peruzzi, Lia PignotTi, Adriano Stinca, Bruno WALlNÖFER \& John WOOD - The Libyan collections in FI (Herbarium Centrale Italicum and Webb Herbarium) and studies on the Libyan Flora by R. Pampanini. [Bocconea, 27(2), ISSN 1120-4060 (print), 2280-3882 (online).] - Herbarium Mediterraneum Panormitanum, Palermo, 2015. 132 pages, 10 black-and-white figures (photographs, maps), 2 tables; paper. [Received January 2016].

The Libyan Herbarium in Florence (FI), which goes back to Pampanini, was kept as a separate unit until 1988. After that date it was incorporated in the Herbarium Centrale Italicum, where it can still be individuated by being kept in separate folders. The Libyan phanerogam material at FI, estimated to comprise ca. 23,000 specimens, is one of the most important extant collections for that country, reflecting Libya's status of an Italian colony from 1911 to the end of World War II. To compare: Libya's largest own herbarium, at Tripoli (ULT), avows N African holdings of 35,000 specimens. The Florence material served as a basis for the description of a considerable number of new taxa, mostly by Pampanini himself and predominantly of infraspecific rank (variety or forma), for the names of which the types, mostly not yet designated, are expected to be found there.

The present publication, coordinated by Cuccuini and Nepi, is apt to focus public awareness on the neglected treasures of this unique collection. An account of the collection's history and its main artisans, the collectors, is followed by the enumeration of 
angiosperm taxa described from it as new and of the types of their names, ordered by alphabetically arranged families, letters A to M. The second half, pertaining to families initialled $\mathrm{N}$ to $\mathrm{Z}$, we will have to await some more. Note that family names, with two exceptions (Capparaceae and Chenopodiaceae, here maintained) are those accepted in Dobignard \& Chatelain's Index synonymique de la flore d'Afrique du Nord. Each of the so far 240 names is referred to the currently accepted taxon; previous type designations are mentioned whenever they exist, and when not, typification in most cases is effected here.

The text is not always easy to read and understand, partly due to linguistic problems and partly owing to the authors' idiosyncratic use of nomenclatural terms. In particular: types have no rank (one can speak of categories of types); when there are syntypes there cannot be a holotype (see Allium aschersonianum f. laeve), and when the "protologue does not mention any specimen" there cannot be syntypes (see Pachyctenium mirabile); besides, the "type" designated for the latter name (the epithet of which is repeatedly misspelled "mirabilis") is not a specimen as defined by the Code, but part of a specimen, which is why the designation is ineffective. These are trivial points, for sure; yet the authors might perhaps better seek competent nomenclatural advice when writing up the second half of their paper - with which they are strongly encouraged to proceed.

W.G.

\section{Congresses and Meetings}

27. Lorenzo Peruzzi \& Gianniantonio DOMina (ed.) - Società Botanica Italiana, Gruppo per la Floristica, Sistematica ed Evoluzione. Approfondimenti floristici e sistematici sulla flora d'Italia. Dedicato a Edda Lattanzi in occa- sione dei suoi 85 anni. Comunicazioni. Orto Botanico, La Sapienza Università di Roma, 20-21 novembre 2015. - Società Botanica Italiana, Firenze, 2015 (ISBN 978-88-85915-17-6). 66 pages, 4 black-and-white photographs; paper. [Received November 2015].

This pamphlet is dedicated to Roman botanist Edda Lattanzi on the occasion of her $85^{\text {th }}$ birthday. It begins with an illustrated digest of her botanical career and activities, by some of her friends and admirers, followed by a list of her published work. After which come short versions (two pages each) of 23 papers or workbench reports presented at the annual meeting of the SBI's Gruppo per la Floristica, Sistematica ed Evoluzione. Most are referred to particular species (Cnidium silaifolium, Dracocephalum austriacum, Viola kitaibeliana), species groups (Allium cupanii, Centaurea panormitana, Silene colorata, Trifolium vesiculosum) or genera (Alchemilla, Bellevalia, Dipterosperma, Lycopus, Pancratium, Pinguicula, Pulmonaria), some to particular areas or regions, habitats (glaciers, temporary ponds) or botanists (Savi, Visiani). As before (see OPTIMA Newslett. 42: (21). 2015), the aim is not to present concrete results but rather to inform on current projects and ongoing research.

W.G.

\section{Daniel JeAnMONOD (ed.) - Le rôle des jardins botaniques alpins dans le monde moderne [Mémoires de la So- ciété botanique de Genève, 4, ISSN 0250-166x.] - Société Botanique, Ge- nève, 2016 (ISBN 978-2-8278-0047-6). 74 pages, photographs in colour and grayscale, graphs, maps; paper. [Re- ceived June 2016.]}

The $125^{\text {th }}$ anniversary celebrations of the Alpine Botanic Garden "La Linnaea" at Bourg-Saint-Pierre, Valais, Switzerland, included a one-day scientific symposium held 
on its premises on July 5, 2014. Founded by Geneva horticulturist and botanist Henry Correvon with the prime purpose of raising, studying and crossing high-mountain plants, "La Linnaea" soon became a renowned base for scientific studies; later, under the leadership of Robert Chodat, chairholder of Botany at Geneva University, developed into an internationally active centre for academic training and research. Its plant collections are currently being taken care of by the Conservatoire Botanique, City of Geneva.

This proceedings volume includes 8 of the 9 lectures held during the jubilee symposium, spanning a wide range of subjects related to Alpine botany and the role of Alpine botanic gardens, from their history to their current significance for research, conservation, and education. It is dedicated to the memory of Jaques Naef, long-time president of the academic committee in charge of the Garden.

W.G.

\section{Festschrift}

29. Franco PEDRotTi \& Gianniantonio DOMINA (ed.) - Festschrift for Francesco Maria RAIMONDO on the occasion of his $\mathbf{7 0}^{\text {th }}$ birthday. [Flora mediterranea, 25 (special issue), ISSN 11204052 (print), 2240-4538 (online).] Herbarium Mediterraneum Panormitanum, Palermo, [2015-]2016. 315 pages, blackand-white illustrations (photographs, maps), tables; paper. [Received January 2016].

A special volume of a journal founded by himself has been published to commemorate the $70^{\text {th }}$ birthday of Francesco Maria Raimondo, OPTIMA President - to mention but one of the prestigious charges he has held along his rich, busy and utterly produc- tive botanical career. It includes 25 papers dedicated to him by his friends and admirers, all but one on topics related to Mediterranean botany. Studies of vegetation and phytogeography are included alongside others on bryophytes and fungi (Italian Pleurotus). Vernon Heywood's essay on Mediterranean botanic gardens will come as a special titbit to Franco who has spent years to successfully restore the Palermo Garden to its former splendour and endear it to the city's population.

Most papers, however, deal with the taxonomy of Mediterranean plants. If my count is accurate, 15 species and one subspecies have been first described and named here, three of them dedicated to the birthday boy: Isatis raimondoi, Centaurea raimondoi (which I would place in Cyanus), and Clinopodium raimondoi. There is also a new Turkish fritillary (Fritillaria asumaniae) and two taxa of Armeria from peninsular Italy, for which area Arrigoni has revised the genus. But it is Brullo \& al. who take the biscuit in revising the Allium cupanii group, which they pulverise into a full dozen of species, ten newly described (which on the basis of their descriptions can all be safely synonymised, four with A. hirtovaginatum and six with $A$. cupanii).

A Palermo publication has by rights to be belated, and this one is no exception. Raimondo himself would probably not have been comfortable had the book been presented to him on a platter along with the birthday cake. Much better after a year and some, as anyway he does not look seventy yet. The artisans, not of the delay (that's the authors' fault) but of having the volume published, Franco Pedrotti and Gianniantonio Domina, deserve our congratulations, which they may accept with justified pride.

W.G. 


\section{OPTIMA COMMISSIONS AND COMMITTEES}

\section{(2013-2019)}

\section{Commission on Bryophytes}

Secretary: R. M. Ros, Murcia

E-mail: rmros@um.es

\section{Commission for Common Names}

Secretary: M. Aghababyan, Erevan

E-mail: m_agababian@hotmail.com

\section{Commission for DNA Banking}

Chairs: M. Bou Dagher Kharrat

A. Scialabba, Palermo

E-mail: magda.boudagher@usj.edu.lb

\section{Commission for the conservation of Economically important and Endemic Plants}

Chair: V. H. Haywood, Reading

Secretary: J.M. Iriondo

E-mail : jose.iriondo@urjc.es

\section{Commission for the Diffusion on Knowledge on Mediterranean Plants}

Chair: O. Vasić, Beograd

Secretary: U. Plittman, Jerusalem

E-mail: uzi@vms.huji.ac.il

\section{Commission on Fungi}

Chair: G. Venturella, Palermo

Secretary: G. I. Zervakis, Athens

E-mail: zervakis@aua.gr

\section{Itinera Mediterranea Commission}

Chair: B. Valdés, Sevilla

Secretary: E. Vitek, Wien

E-mail: ernst.vitek@nhm-wien.ac.at

\section{Lichen Commission}

Secretary: A. R. Burgaz Moreno, Madrid

E-mail: arburgaz@bio.ucm.es

\author{
Commission on Mediterranean Type \\ Material
}

Chair: J. Molina, Montpellier

Secretary: G. Domina, Palermo

E-mail: gianniantonio.domina@unipa.it

\section{OPTIMA Herbarium and Library Commission}

Chair: W. Greuter, Palermo \& Berlin Secretary: F. M. Raimondo, Palermo E-mail : francesco.raimondo@unipa.it

Commission for Karyosystematics and Molecular Systematics

Chair: G. Kamari, Patras

Secretary: C. Blanché, Barcelona

E-mail : cesarblanche@ub.edu

\section{Commission for Mediterranean Ethnobotany (2016-2019)}

Chair: J. Vallès, Barcelona

Secretary: T. Ulian, Kew

E-mail : t.ulian@kew.org

Web Commission (2016-2019)

Chair: K. Hüsnü Can Baser, Eskişehir

Secretary: G. Domina, Palermo

E-mail: gianniantonio.domina@unipa.it

\section{Prize Commission}

Secretary: G. Domina, Palermo

E-mail: gianniantonio.domina@unipa.it

Submission of contributions to OPTIMA Newsletter: Articles and news related to Mediterranean botany are welcome. Please send all texts as a Microsoft Word file to the pertinent Commission Secretary, or directly to the OPTIMA Secretariat. 
OPTIMA Newsletter 43

\section{Contents}

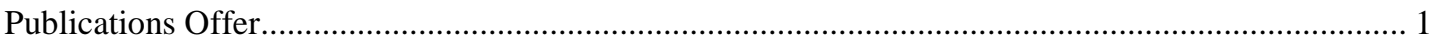

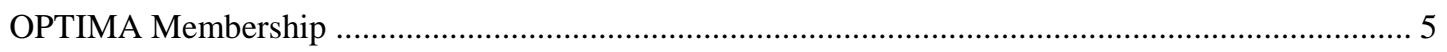

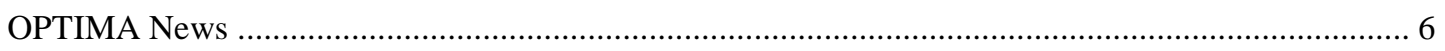

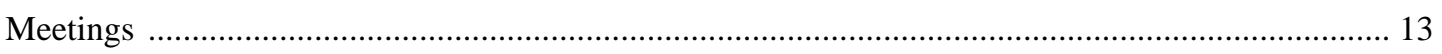

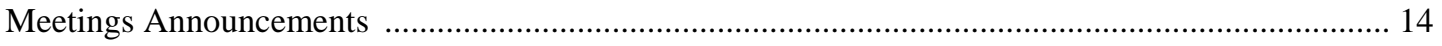

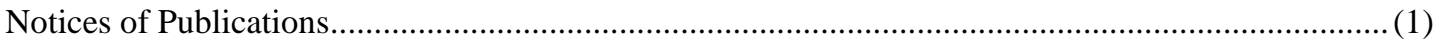

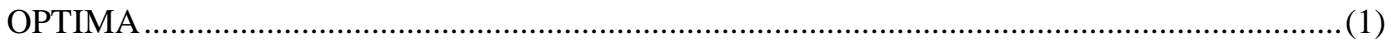

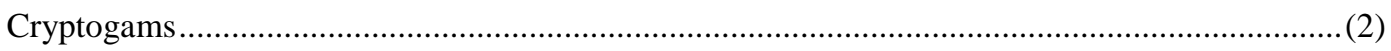

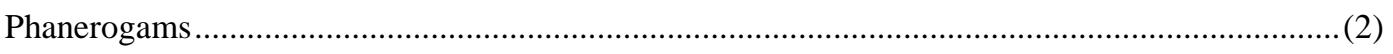

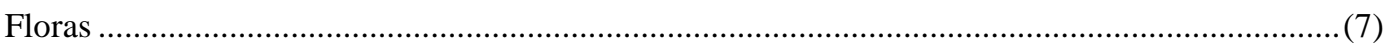

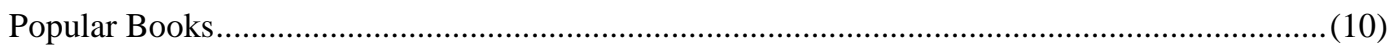

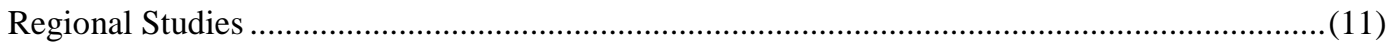

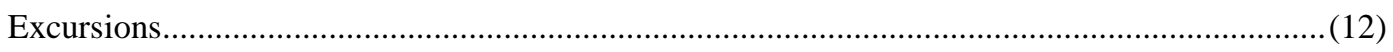

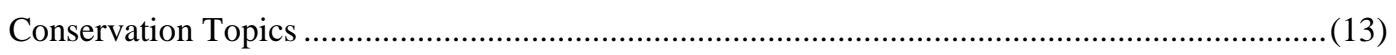

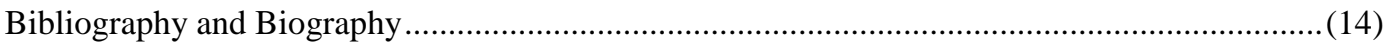

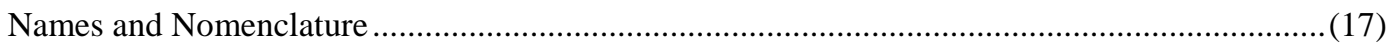

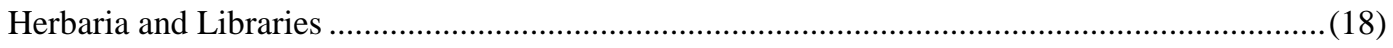

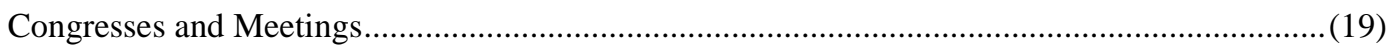

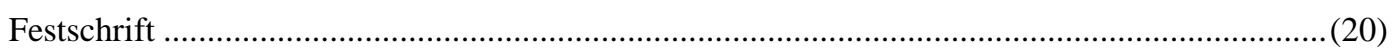

